\title{
Growing rubber in Uva, Northern and Eastern provinces of Sri Lanka: Importance of an effective institutional role
}

\author{
D M A P Dissanayake* and Wasana Wijesuriya* \\ *Rubber Research Institute of Sri Lanka, Dartonfield, Agalawatta, Sri Lanka
}

Received 28 December 2012

\begin{abstract}
There is ample evidence that people in Uva, Northern and Eastern provinces are very enthusiastic about rubber farming. The younger generation prefers rubber cultivation in these areas and the majority of the farmers believed that there will be improvement in their social status due to involvement in rubber industry. The community was confident that the involvement in rubber farming will create an efficient and enthusiastic environment in their lives and was confident about the next generation's involvement in rubber industry. Majority of the farmers were willing to use family labour for rubber planting. Interest taken by the government, availability of the subsidy, popularity of the rubber crop and easy farming operations were considered as positive factors by the farmers in selecting rubber cultivation as a source of income. The institutions those are responsible for rubber farming have an important role to play in making use of farmers' enthusiasm for rubber farming.

One of the issues which need involvement of Ministry of Plantation Industries (MPI), and Rubber Development Department (RDD) is timely issue of subsidy and inputs to farmers. Thurusaviya Fund (TF) has a role to play in establishment, registration and organizing of smallholder rubber societies and providing processing facilities and enhance sales and marketing of rubber. Rubber Research Institute should involve in research and development activities pertaining to assessment of vulnerability and finding adaptation measures for adverse weather conditions since the environment in nontraditional areas is not very conducive for planting of rubber. Further, a mechanism is necessary to ensure adoption of recommended practices perhaps through effective extension methods to make rubber farming a profitable and sustainable venture.
\end{abstract}

Key words: non-traditional areas, preparedness, rubber, smallholder, willingness

\section{Introduction}

The strategic initiatives identified to reach the national targets in rubber production are, increasing productivity and extent under cultivation. The state response towards these strategies is very 
positive, giving emphasis on growing rubber in non-traditional areas in Uva, Eastern and Northern provinces where land and labour are assumed to be nonlimiting factors. If properly implemented, the rubber planting programmes in these areas will alleviate poverty of the people and ensure environmental sustainability.

The non-traditional rubber growing areas have been focused in many development projects aiming the rural poor but with very little prospective results. Many development programmes have failed due to insufficient attention on the needs and thoughts of the community, in the planning process. There is some obvious evidence since Uva province is among the poorest with a poverty Head Count Index ${ }^{1}$ (HCI) of $13.7 \%$ while Moneragala and Badulla districts have HCIs of $14.5 \%$ and $13.3 \%$, respectively and being ranked as $3^{\text {rd }}$ and $4^{\text {th }}$ districts based on this index (Department of Census \& Statistics, 2011). With this background, there is a risk of resource wastage unless proper planning is done at the initial stages of the rubber development programmes. This is especially important in development of the smallholder sector where resource wastage is expected to be high due to poor awareness and adoption of technical recommendations related to rubber planting and processing.

${ }^{1}$ Size of poor population fall underneath the poverty line
Being a new initiative, there is a high degree of uncertainty about the sustainability of this attempt on expanding rubber into non-traditional areas due to inadequacy in knowledge on environmental, socio-economic, technological and institutional aspects. In the presence of very high enthusiasm among the farmers in these areas on rubber farming, if the state institutions can play a pivotal role, rubber growing in non-traditional areas can create a win-win situation.

A detail study was conducted to investigate the above issues in the Moneragala district and in some parts of Ampara and Badulla districts under the Coordinated Thematic Research Programme (CTRP) of the National Science Foundation (NSF) (Wijesuriya, 2010). This study attempted to identify the issues and perspectives of rubber farmers to rectify inadequacies in knowledge on environmental, social, economic, technological and institutional aspects which exist in different magnitudes. There have been several publications resulting from this project; on issues and perspectives of smallholder rubber farmers and possible solutions for sustainable rubber farming in non-traditional rubber growing areas (Wijesuriya et al., 2008), priorities for technology transfer (Wijesuriya et al., 2010), constraints in smallholder rubber farming (Wijesuriya et al., 2011), land suitability model for Moneragala district, a first approximation using GIS (Karunaratne et al., 2011) and on socio- 
Institutional role in promoting rubber cultivation

economic status of smallholder rubber farmers (Dissanayake et al., 2010).

This paper will focus on two main areas; namely, the farmers' concerns and the role to be played by the state institutions in making use of farmers' enthusiasm to achieve the expected goals of rubber farming in nontraditional areas. The paper will also elaborate on strategies adopted in technology transfer for sustainable rubber cultivation.

\section{Methodology}

A questionnaire was designed to gather information falling into socio-economic, environmental, technological and institutional aspects of the smallholder rubber farmers who expect to start rubber cultivation (potential rubber growers). A total of 255 potential rubber farmers were interviewed in 2008 in Moneragala, Badulla and Ampara districts. Information collected from a study in the Siyambalanduwa DS division (the DS division with the least extent under rubber) which covered the GN divisions, viz. Kotiyagala, Gemunupura, Janapada wasama, Minipura, Tissapura, Wategama, Siripura, Wijayapura, Ethimale, and Perakumpura, which was carried out in 2012 with 106 respondents is also employed as there was no representation due to inadequacy of information of this DS division in the previous study. Although Siyambalanduwa DS division recorded the least extent under rubber in Moneragala district, there is about 476 ha, 3345 ha and 350 ha under the respective categories of 'most suitable', 'suitable' and 'moderately suitable' categories for growing rubber (Karunaratne et al., 2011) and hence there is a considerable scope for further expansion of rubber cultivation. The results of focus group interviews conducted in finding the issues related to rubber cultivation are also presented in this paper.

\section{Results and Discussion \\ Socioeconomic details of rubber farmers}

As reported by Dissanayake et al. (2010), there was an indication of the younger generation's preference for rubber cultivation in these areas. The proportion under 50 years of age is more under categories of 'potential' and farmers who own immature holdings compared to farmers who own mature holdings. The proportion of smallholder farmers under 40 years of age was about $17 \%$ in traditional rubber growing areas, which is comparatively low compared to non-traditional rubber growing areas (Wijesuriya et al., 2007). More than $50 \%$ of the farmers had only primary level education. The recent study conducted in the Siyambalanduwa DS division in 2012, reported a percentage of $67 \%$ with primary education whilst $7 \%$ have not attended school. Hence, education can be considered as a constraint in improving the awareness of rubber farmers in the nontraditional rubber growing areas.

Low capital availability was identified as a 'weakness' in a SWOT analysis 
D M A P Dissanayake and Wasana Wijesuriya

done in Moneragala district (Dissanayake et al., 2005a). There is a higher percentage of farmers with a monthly income of less than Rs.10000 in this district. The improvement in economic status is evident in the category who own mature rubber plantations. It was reported in a previous study in selected rubber growing areas in the Moneragala district, $50 \%$ of the rubber smallholders are poor (Herath et al., 2005). Possible solutions to alleviate poverty in Moneragala district have been suggested by Dissanayake et al., (2005b). The percentage with a monthly income of less than Rs.10000 is 75\% while a considerable proportion $(17 \%)$ receives a monthly income between Rs.10000 to Rs.20000 (Dissanayake et al., 2010). This situation suggests that low income is a bottleneck in adoption of recommended technologies as they are likely to use the funds for other purposes. Hence, proper monitoring methodologies need to be adopted to ensure proper use of funds. A summary of key socioeconomic indicators of 'potential' rubber farmers is given in Table 1.

The income distribution according to the survey conducted in some areas of the Siyambalanduwa DS division in May 2012 is given in Table 2. An improved situation is found, where the proportion receiving less than Rs 10000 has been reduced to $20 \%$, which is fairly close to what farmers who own mature rubber receive. However, it should be noted that expenses on basic items have increased to a certain extent. The percentage families below the poverty line (HCI) have been also reduced in the Moneragala district from $33.2 \%$ in $2006 / 07$ to $14.5 \%$ in 2009/2010 (Department of Census \& Statistics, 2011).

Table 1. Key socio-economic characteristics of 'potential' rubber farmers

\begin{tabular}{lc}
\hline Characteristic & Value \\
\hline Size of household (No.) & $\begin{array}{c}\text { Range: 1-8 } \\
\text { Average: 4 }\end{array}$ \\
\hline Female smallholders (\%) & 22 \\
\hline Age structure (\%) & \\
Under 40 years & 34 \\
40-49 years & 35 \\
50-59 years & 26 \\
60 \& above & 5 \\
\hline Level of education (\%) & \\
No schooling & 2 \\
Primary & 51 \\
OL & 36 \\
AL \& higher & 15 \\
\hline Level of income (\%) & \\
<Rs. 10000 & 57 \\
Rs. 10001-25000 & 31 \\
Rs. 25001-50000 & 10 \\
>Rs. 50000 & 2 \\
\hline
\end{tabular}

Source: Dissanayake et al. (2010)

The majority of the respondents in the survey conducted in the Siyambalanduwa DS division were farmers (83\%) (Fig. 1). In other areas of the Moneragala district, $78 \%$ are farmers, $13 \%$ involved in business activities and 9\% employed in government jobs. 
Institutional role in promoting rubber cultivation

Table 2. Income distribution of respondents in the Siyambalanduwa DS division

\begin{tabular}{lc}
\hline Level of income (Rs) & \% of respondents \\
\hline <Rs. 10000 & 20 \\
Rs. 10001-25000 & 45 \\
Rs. 25001-50000 & 27 \\
>Rs. 50000 & 8 \\
\hline
\end{tabular}

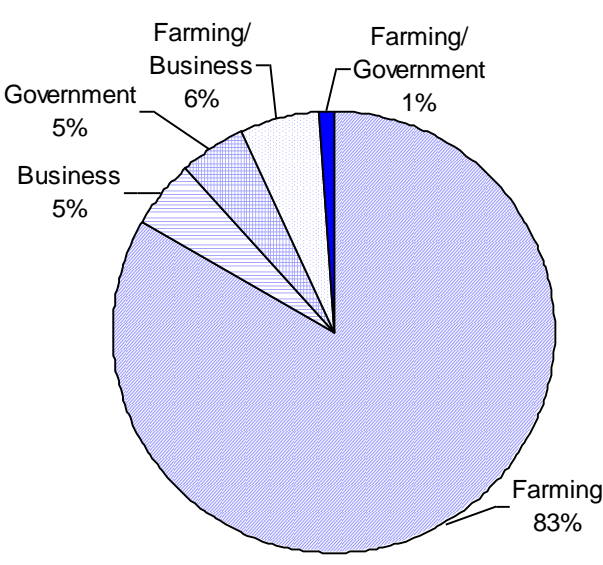

Fig. 1. Involvement in different activities by respondents in Siyambalanduwa DS division

\section{Preparedness and willingness of farmers}

As per the study by Wijesuriya (2010), the majority of the farmers $(80 \%)$ believed that there will be improvement in their social status due to involvement in rubber industry. According to the recent study done in Siyambalanduwa DS division, $95 \%$ of the respondents believed that there will be improvement in their social status if they can engage in rubber industry. In response to a question on what type of a conversion is expected by involving in the rubber industry, the earlier study reported $75 \%$ whilst in the recent survey, $94 \%$ was confident that the involvement will create an efficient and enthusiastic environment in their lives. The earlier study reported that $37 \%$ of the sample was confident about the next generation's involvement in rubber industry while $59 \%$ was uncertain and $4 \%$ said 'no' in response to this question. Majority of the farmers (69\%) were willing to use family labour for the immediate activity, viz. land preparation. In the recent study, 59\% of the sample was confident about the next generation's involvement in rubber industry while $29 \%$ was uncertain and $12 \%$ has given negative responses. The farmers were willing to help each other by offering labour (Atthama) and $84 \%$ of the sample were prepared to use family labour for land preparation.

In the sample of 'potential' rubber growers, $38 \%$ had already prepared the land for planting and $45 \%$ of them were preparing lands during the period when the survey was done. The rest, about $17 \%$ have not taken any steps for land preparation. Eighty nine percent of the farmers in the sample have applied for the permits for rubber cultivation and among them $38 \%$ were issued with permits. Yet, the percentage who received planting material was below $1 \%$. Majority of the sample $(96 \%)$ had no idea of the clone that they are going to plant in their lands while $4 \%$ stated that it will be RRIC 121. Poly bagged plants were preferred by $68 \%$ of the 
farmers and the rest did not have a clear idea about the planting material they will receive for planting. Ninety six percent of the sample was hoping to receive the plants from the Government nurseries (through the subsidy) and about $1 \%$ wished to purchase planting material from private nurseries while the rest of the sample (3\%) had no idea about purchasing of planting material. In response to a question on whether they are prepared to grow intercrops in their land, $82 \%$ of them were positive towards planting intercrops. Banana as an intercrop was preferred by the majority (81\%), while corn was preferred next with a percentage of $9 \%$. The other preferences were sugarcane, pineapple, vegetables, lime and cocoa. Nearly $52 \%$ of the sample was prepared to sell the intercrops, $43 \%$ will consume and sell their produce and 5\% stated that they will use intercrops for home consumption.

The respondents in the recent study were very keen on converting to rubber cultivation because of the fixed income. They considered rubber as an easy crop. They mentioned about land preparation in rubber which is a need, once in a planting cycle in contrast to yearly land preparation which is a tedious practice in chena cultivation. They also mentioned about the timber value of rubber and most of them knew about the environmental benefits of growing rubber. Some came out with the suggestion of planting intercrops. Several farmers expressed their eagerness mainly to receive a land for a permanent crop. They were very concerned to know about rubber planting since rubber is totally a new crop to most of them. Some of them mentioned that at present they totally depend on dealers who help the farmers to purchase their agricultural needs. This system however is not conducive for farmers since most of them were of the view that they do not get a reasonable price for their produce by selling back their produce to the dealers. The farmers considered rubber as a good income source and it was the main reason for selecting rubber (Fig. 2). Interest taken by the government, availability of a subsidy, popularity of the rubber crop and easy farming operations were considered as positive factors by the farmers in selecting rubber cultivation as a source of income.

The enthusiasm for rubber cultivation is evident from the participation in participatory workshops. Matrix ranking was used to gather information on this as a participatory tool. The farmers have listed the important crops in the area and criteria they consider in selecting a suitable crop for the area. In the next step they allocated weights for each crop considering a single criterion at once. The criteria used by farmers are listed in Table 3.

The matrix-ranking exercise done on the basis of these criteria, rubber is preferred over the other crops based on these environmental, economic, technological and institutional considerations (Wijesuriya et al., 2008). 
Institutional role in promoting rubber cultivation

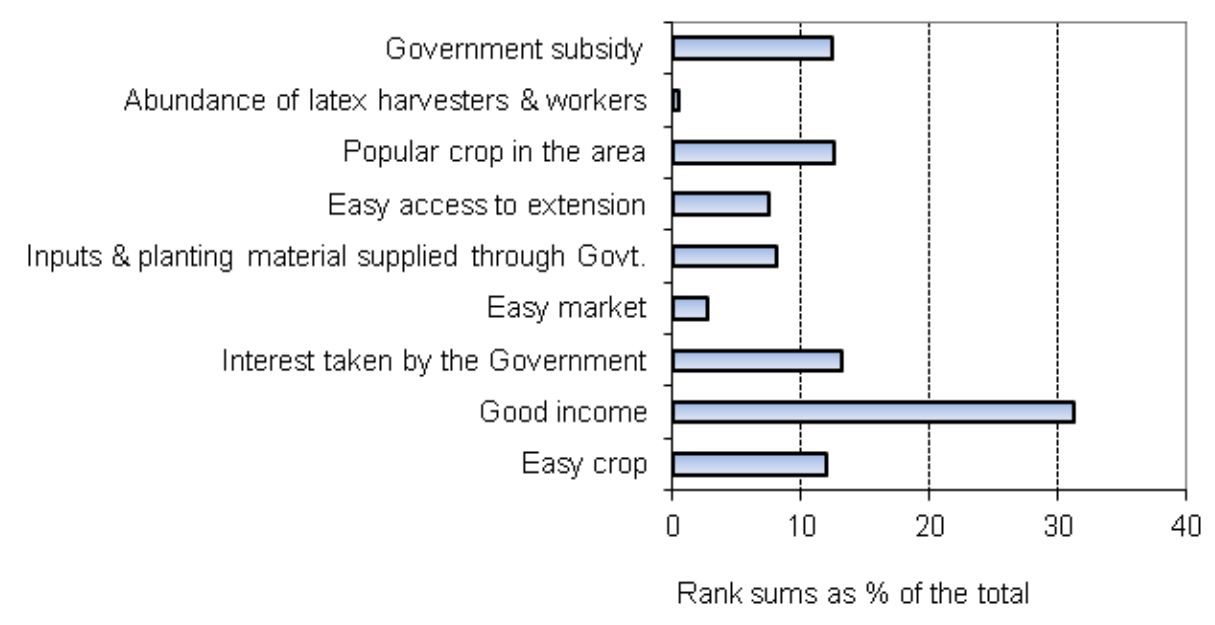

Fig. 2. Reasons given by farmers for selecting rubber

Table 3. Criteria used by farmers to select crops for planting

\begin{tabular}{ll}
\hline Aspects & Criteria \\
\hline Environmental & Tolerance to droughts \\
& Tolerance to pests and diseases \\
Economic & Profitability \\
& Income throughout the year \\
& Market facilities \\
& Long term income \\
Technological & Easy planting \\
& Knowledge on the crop \\
Institutional & Government interventions \\
& Advisory services \\
& Supply of inputs \\
\hline
\end{tabular}

\section{Role of institutions in the} development process of nontraditional areas

There are several institutions that cater to the needs of the smallholder rubber sector in Sri Lanka. Ministry of Plantation Industries (MPI) is the governing body of the Rubber Research
Board (RRB), Rubber Development Department (RDD) and Thurusaviya Fund (TF). Rubber Research Institute of Sri Lanka (RRISL) is responsible for research and development activities which are under RRB. RRISL has a separate department named, Advisory Services Department (ASD) which is its 
extension arm. RDD is responsible for issuing permits for rubber planting, subsidy disbursement and providing planting material to the smallholders. $\mathrm{TF}$ is a body responsible for establishment, registration and organizing of Thurusaviya societies (smallholder rubber societies) and to provide processing facilities, enhance sales and marketing of rubber.

Some of the issues which need involvement of MPI, RDD and TF directly are elaborated in this paragraph. The majority of farmers who were involved in participatory studies were 'potential' rubber growers who had already received permits for rubber cultivation. Hence, the major issues in most of the areas were related to planting material. Due to the high demand for planting material, poor quality planting material have been released to the farmers in certain occasions. Some farmers have raised the issue of difficulty in getting permits for rubber cultivation, as they had not received permits from Divisional Secretariats for cultivation (Nearly $53 \%$ of the survey sample stated that they occupy state owned land on lease or having 'Swarnabhoomi' or 'Jayabhoomi' deeds and some are encroachers). Further, delay in subsidy payments and marketing problems were also raised as major issues in some areas. On the issue of limitation in planting material, the respondents suggested to have nurseries at village level. It was mentioned by respondents in Siyambalagune in Wellawaye that they have nurseries at village level and planting material is not an issue of priority for them. It is also needed to educate farmers on the subsidy scheme to avoid any delays and misunderstandings with institutions. Several institutional issues like insufficient extension workers and frequent transfers need to be addressed well in policy documents as they can severely affect the sustainability of the system.

Encouraging and helping farmers to put up farmers' organizations have been an effective approach towards development. Processing, marketing and pricing issues can be best handled through organizing the farmers through societies. With the formation of an organization, the farming community can be empowered with the knowledge and skills to identify its needs and problems, harnessed its resources to deal with these problems and take actions collectively. Furthermore, it is the take-off point for some of our strategies. However, this situation does not exist at a sound level in the smallholder rubber sector, as commented by the farmers themselves. Strengthening the existing farmer societies should be among the priorities in this respect.

Poor knowledge and lack of training facilities were also raised as major issues in some areas. These issues suggest that there is a felt need for improving awareness. Several projects were undertaken by the Rubber Research Institute of Sri Lanka (RRISL) 
Institutional role in promoting rubber cultivation

with the aim of improving awareness in the non-traditional rubber growing areas of Sri Lanka funded by local and international agencies (Dissanayake et al., 2005b; Wijesuriya et al., 2005; Rodrigo \& Iqbal, 2009). It was apparent that there is a considerable improvement in awareness on recommendations where the above mentioned studies were focused on.

The environmental issues such as prolonged drought periods in these areas need to be very promptly addressed with possible adaptation methods to minimize adverse environmental effects. Raising awareness on soil and moisture conservation is of immense importance in this regard. The ongoing study titled "Empowering rubber farmers in non-traditional rubber growing areas through knowledge on combating adverse impacts of environment for better productivity" is in progress to identify vulnerability of rubber in non traditional rubber growing areas to environmental threats, to develop and test appropriate adaptation measures to combat adverse environmental conditions in these areas and to disseminate knowledge on technical recommendations to a wider audience of rubber farmers, stakeholders and policy makers. This study covers Uva, Eastern and Northern provinces of Sri Lanka.

However, in general there appear to be certain socio-economic factors other than poor awareness that hinder adoption of recommendations in these non-traditional rubber growing areas.
Poor education, low income levels and poor group involvements of smallholder farmers were some of the factors for poor adoption rates of recommendations in these areas. Certain institutional issues were also raised by farmers during the study emphasizing the need for an efficient extension service to them (Wijesuriya et al., 2008).

There is no guaranteed procedure to ensure the transfer of any technology because of the variability of situations and conditions surrounding the popularization process. However, to make fine results on the ground the strategies need to be focused on the following; viz. a) development of appropriate technology, b) transfer of developed technologies together with needy knowledge, c) promoting avenues for adoption and diffusion of transferred technologies, d) creation of a suitable environment for implementation and e) revitalizing Government policies.

Identification of problems and development of recommendations only by the researchers themselves resulted in low adoption levels in most instances, which are not affordable, especially for small-scale farmers. There have been several adaptive research trials in farmers' fields conducted by RRISL in collaboration with the farmers. However, better success would have been achieved through collaboration by means of understanding farmers' perceptions, local knowledge and specific problems. Meaningful dialogues between researchers, extension workers and farmers to share 
experiences gathered at the ground level are of immense importance for development of appropriate technologies. Information through surveys, extension research and participatory approaches can be used to incorporate knowledge and experience gathered in generations by local communities for better success. Also, setting up of some coordinating bodies with representatives from relevant stakeholders will help strengthening the research-extension-farmer linkage.

All technologies recommended for smallholders need to be tested for the smallholder situation through on-farm research methodologies followed by an economic evaluation. RRISL has established 8 participatory on-farm trials in 8 sites (Table 4) covering Northern, Eastern, North Central and Uva provinces by assisting smallholder farmers with knowledge and inputs. Different agricultural practices such as; Irrigation, organic manure incorporation, mulching and
Potassium-Fertilizer are tested in these trials.

The developed technologies need to be penetrated to the farmer level with proper planning by the respective extension managers and operators. In this respect, farmer participation towards a satisfactory level would be of paramount importance in the planning process. Need based extension programmes are the best way to cater to farmers' needs. This can reduce the cost and wastage of resources as well. In addition, a dialogue between RRISL and RDD in the planning process is vital as both ASD and RDD are serving the same target group. This has created differential acceptance of these two groups by the smallholders as a result of poor coordination which leads to wastage of resources through duplication of some services. Hence, regular discussions between institutions at the planning are highly important to overcome such situations.

Table 4. The details of on-farm trials established in 2012 in non-traditional rubber growing areas

\begin{tabular}{llcc}
\hline Location & Extent (Ac.) & Agro-ecological zone & Province \\
\hline 1. Ethiliwewa - Telulla & $1: 0: 00$ & DL1a & Uva \\
2. Siyabalanduwa-Buddama & $0: 3: 00$ & IL2 & Uva \\
3. Siyabalanduwa-Buddama & $1: 0: 00$ & IL2 & Uva \\
4. Namaloya - Kahatagasyaya & $1: 0: 00$ & DL2a & Eastern \\
5. Mahaoya-Unuwathura bubula & $1: 0: 00$ & IL2 & Eastern \\
6. Mahaoya - Kekirihena & $1: 0: 00$ & IL2 & Eastern \\
7.Omanthei- Navi palamotta & $1: 0: 00$ & DL1b & Northern \\
8. Anuradhapura-Nellikulama & $1: 0: 00$ & DL1b & North-Central \\
\hline \hline
\end{tabular}


Institutional role in promoting rubber cultivation

One of the major problems that exist in the present extension service rendered by RRISL is the lack of sufficient number of extension workers to cater the smallholders. An extension officer of RRISL has to provide his services for nearly 3000 farmers, which is not at all a convenient exercise, hindering the effectiveness of the extension service. Every effort should therefore be made to recruit and train additional man power and to provide them with necessary transport and other facilities which are highly inadequate at present. However, to cope up with the present situation, identification of task oriented programmes targeting a maximum number of farmers during the planning stage is essential. This will create a situation for efficient use of allocated limited resources.

Most of the training programmes for farmers are conventional in nature. This resulted in poor attraction by farmers leading to wastage of resources. Therefore, ASD has introduced effective modifications and changes in awareness raising activities. These include, in situ planning of training programmes through awareness and adoption tests, field demonstrations, open discussions, video documentaries on rubber cultivation and processing, mini scale exhibitions and providing opportunities to purchase essential items for rubber farming. Moreover, participation of RDD Officers and private sector organizations involved in the rubber industry strengthened the dialogue between different stakeholders and the rubber farmers. Advisory visits by extension workers are the basic feature of technology transfer but with varying degrees of success. Hence, this was transformed into a farmer requested basis without attending on ad-hoc manner. A new extension strategy group advisory approach named 'Vihidum Sathkara' has been in practice with considerable success. The model of this approach is depicted in Fig. 3. Three programmes of this nature have been done with great success during 2011 in the Moneragala district.

Farmers have a way of convincing other farmers to adopt a technology that they have successfully and profitably utilized. This is the basis for the model farmer and model farm strategy. In our experience, most rubber farmers are generally reluctant to change their farming activities as they have the 'wait-and-see' attitude. Although many farmers are very much open to new ideas and technologies, there are more farmers who would first like to see a working model before they follow the lead. To overcome this situation, model rubber farms have been established in all the rubber growing areas together with this new approach it was exercised in establishing "Pera Gaman Rubber Gammana" - forward marching rubber villages - as a new concept for effective technology transfer. This can also be effective in non-traditional areas. 


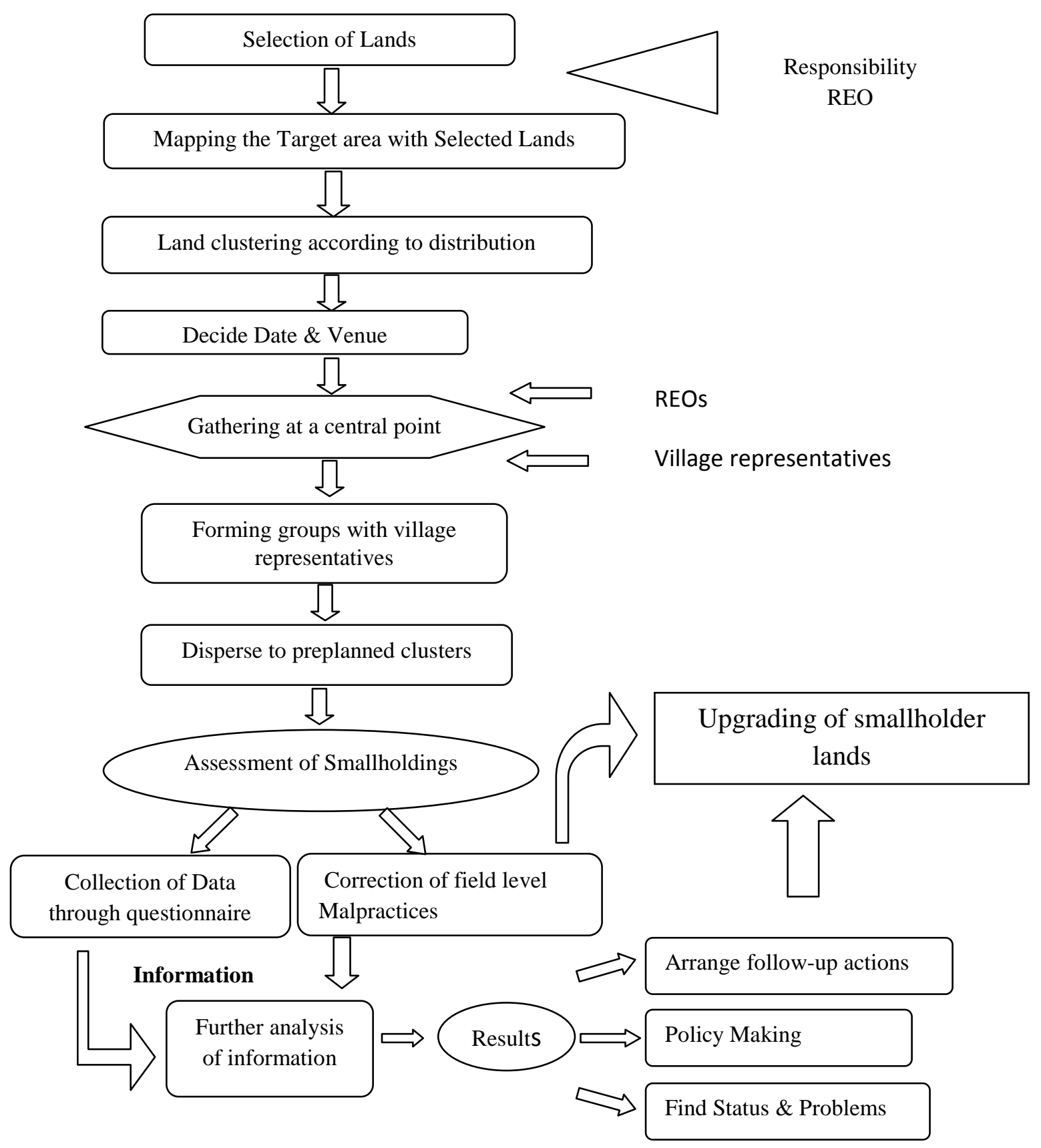

Fig.3. The model for group advisory approach 
Institutional role in promoting rubber cultivation

For effective implementation of strategies, creation of a suitable environment and revitalizing Government policies need to be addressed. Available policies of the rubber industry have prospects and constraints. Rubber farmers gaining benefits through these policies for a long period of time have bitter experiences on receiving subsidies in the form of in-kind and cash. This hindered the expected output of the transfer of respective technologies. In order to help the poor farmers there is a need to revitalize existing policies or formulating new policies to provide credit facilities or develop bank loan schemes.

\section{Acknowledgement}

This article is based on the initial investigations conducted in the project "Empowering rubber farmers in nontraditional rubber growing areas through knowledge on combating adverse impacts of environment for better productivity" funded by National Research Council (NRC) grant No. 11125. The authors are grateful to NRC for the financial assistance. Secondary information collected for this paper was from the studies carried out by RRISL. The extension and experimental officers of RRISL and officers attached to RDD in the Moneragala Regional Office who facilitated questionnaire surveys are also acknowledged.

\section{References}

Department of Census \& Statistics (2011). Poverty indicators. Department of Census \& Statistics, Ministry of Finance \& Planning, Sri Lanka.

Dissanayake, D M A P, Wijesuriya, Wasana, Herath, H M L K and Gunarathna, P K K S (2010). Socioeconomic status of smallholder rubber farmers in the Moneragala district. Journal of Food and Agriculture 3, 4149.

Dissanayake, D M A P, Wijesuriya, Wasana and Abeywardene, Vidura (2005a). Farmers' perspectives: expectations and constraints faced by smallholder rubber farmers in Moneragala. Bulletin of the Rubber Research Institute of Sri Lanka 46, 70-79.

Dissanayake, D M A P, Wijesuriya, Wasana and Edirisinghe, J C (2005b). Smallholder rubber sector in the Moneragala district: Potentials and constraints. Bulletin of the Rubber Research Institute of Sri Lanka 46, 2531.

Herath, Keminda, Wijesuriya, Wasana, Puhambugoda, Rukmal and Abeywardene, Vidura (2005). Income status of rubber smallholders in the Moneragala district: Reporting from participatory rural appraisals done in four villages. Bulletin of the Rubber Research Institute of Sri Lanka 46, 5261.

Karunaratne, Senani, Gunathilake, Jagath, Wijesuriya, Wasana, Herath, Keminda and Samarappuli, Lalani (2011). Land suitability model for rubber in Moneragala district: first approximation using GIS. Journal of the Rubber Research Institute of Sri Lanka 91, 4960. 
D M A P Dissanayake and Wasana Wijesuriya

Rodrigo, V H L and Iqbal, S M M (2009). Rubber reaches east: hand in hand with regaining Sri Lanka. Bulletin of the Rubber Research Institute of Sri Lanka 50, 111-117.

Wijesuriya, B W, Dissanayake, D M A P, Herath, H M L K, Wijeratne, M, Gunarathne, P K K S and Abeywardene, V (2010). Priorities for technology transfer in non-traditional rubber growing areas in Sri Lanka. In: Proceedings of the Third Symposium on Plantation Crop Research - Stakeholder Empowerment through Technological Advance. (Eds. R S Dharmakeerthi and W M P K Senevirathna). Rubber Research Institute of Sri Lanka, Dartonfield, Agalawatta, Sri Lanka. 299310 .

Wijesuriya, Wasana, Disssanayake, D M A P, Herath, H M L K and Gunaratne, P K K S (2011). Constraints in sustainable smallholder rubber farming in the Moneragala district. Journal of the Rubber Research Institute of Sri Lanka 91, 61-73.

Wijesuriya, W, Dissanayake, A, Samarappuli, L, Wijeratne, M, Gunaratne, $\mathrm{K}$ and Abeywardene, V (2008). Issues and perspectives of smallholder rubber farmers and possible solutions for sustainable rubber farming in non-traditional rubber growing areas. In: Proceedings of the Second Symposium on Plantation Crop Research - Export Competitiveness through Quality Improvements. (Eds. N.A.P.D. Nainayake and J.M.T.D. Everad). Coconut Research Institute, Lunuwila, Sri Lanka. 247-256.

Wijesuriya, Wasana, Dissanayake, D M A $\mathrm{P}$, Herath, Keminda, Edirisinghe, Jagath and Abeywardene, Vidura (2007). Some issues related to sustainability in the smallholder rubber sector: a case study of three major rubber growing districts, Journal of the Rubber Research Institute of Sri Lanka 88, 59-76.

Wijesuriya, Wasana (2010). An approach towards sustainable development and economics of the smallholder rubber sector. Final Report submitted to National Science Foundation, Grant No: RG/2006/EPSD/01, Rubber Research Institute of Sri Lanka.

Wijesuriya, Wasana, Dharmadasa, M, Ratnayaka, Susith, Abeydissanayake, D R A M G and Sarath Chandrasiri, J A (2005). Level of awareness on recommended practices in rubber smallholdings in the Moneragala district. Bulletin of the Rubber Research Institute of Sri Lanka 46, 44-51.

Address for correspondence: Dr D M A P Dissanayake, Head, Advisory Services Dept., Rubber Research Institute of Sri Lanka, Telewala Road, Ratmalana, Sri Lanka.

e-mail: anurapd@gmail.com. 